now an acknowledged world authority. This was an enthusiasm which Gregory shared and which is somehow reflected in much of his later work. But probably the most important influences on Bateson's thinking came from his close friend $\mathrm{C}$. $\mathrm{H}$. Waddington, the Edinburgh geneticist. Gregory never adopted the Marxist view of science favoured by Waddington, but he did share many of the latter's humanist concerns. What these concerns were is summed up in the titles of Gregory's last two substantial publications, an essay collection, Steps to an Ecology of Mind (1972), and Mind and Nature: A Necessary Unity (1979), the latter written at a time when Gregory was fully aware that he was suffering from terminal cancer.

Gregory was not a vitalist; he saw very clearly that the scientific explanation of human behaviour must be of essentially the same kind as the scientific explanation of the behaviour of dolphins. But he was too good a cultural anthropologist to be taken in by the kind of reductionism that is favoured by some of the more simpleminded sociobiologists. The human mind cannot be explained away either as a genetically pre-programmed machine or as an illusory side effect of conditioned reflexes.

Gregory's interests always remained biological; but the focus of his attention was not confined to the human being as a biological organism. It was Man in his social interactions and Man as a species adapted to extremely sophisticated forms of interpersonal communication that provoked his most challenging suggestions. But they were suggestions rather than proven facts. His theories about the nature of schizophrenia and about "the double bind" influenced a wide variety of practising psychotherapists, but they were often misunderstood and they were not of a sort which lend themselves to verification.

Academically he was always a loner; he seldom occupied any position which called for formal teaching. He exercised his influence in private informal seminars and conference discussions and it is difficult to pin down just what that influence was. Gregory was a guru. I know that I myself found him one of the most exciting and inspiring "teachers" I have ever met.

Gregory himself would probably have claimed that his main claim to fame was his application of ideas borrowed from cybernetics to an understanding of the feedback which occurs in person to person interactions. But what he had to say on such matters often contained a good deal of blarney; he had a scientific attitude, but he was not an exact scientist and he was not a mathematician.

Lipset recognizes these limitations. Inspired in his youth by the art of Blake and the laws of Mendel, Gregory aspired to make comparable innovations. He did not succeed, but his contributions to our understanding of the position of mind in

\section{IMAGE \\ UNAVAILABLE FOR COPYRIGHT REASONS}

From left: Gregory Bateson, Margaret Mead, Lois Bateson and Barkev Kasarjian

the physical world and to the complex relationships which link form and process are far from negligible.

There is much more to Lipset's book than I have been able to summarize here. The account of the intellectual atmosphere in which Gregory grew up is particularly impressive. The book as a whole makes a most timely and fitting memorial.

Edmund Leach is a Fellow of King's College, Cambridge.

\title{
Beveridge on discovery
}

\section{P. B. Medawar}

Seeds of Discovery. By W.I.B. Beveridge. Pp.130. (Heinemann/W.W. Norton: 1980.) Hardback £6.95, \$12.95; paperback £3.90.

THIS book is a sequel to the author's lively and readable The Art of Scientific Investigation (Heinemann, 1957). Seeds is readable too - not least because of the wealth of anecdotes and other illustrative material which help the author to make his points; it is a learned man who will learn nothing from Beveridge's pages. Amidst much that is familiar I was very interested to learn that a former Vice President of the National Academy of Sciences had published a demonstration that flight by heavier-than-air machines was not possible.

The present book is not nearly such a success, unfortunately; it is not very original and is in places lamentably trite. Nowhere was I struck, as one always hopes to be, by some felicity of thought or writing. Indeed, I found myself in the disagreeable position of having reason constantly to find fault. As to triteness, consider such a passage as this:

Scientists do not work in isolation. All are members of the world-wide scientific community. It is joined together by communication through scientific journals and meetings, which are an essential part of science. Formal and informal discussions at scientific meetings, sometimes involving conflict of views and arguments, are a feature of the scientific life.

This is the writing of someone who has nothing very original to say.

The book throughout has a slightly aggrieved and truculent air arising mainly out of the very low opinion Beveridge holds of philosophers of science, whom he accuses of trying to foist on us the notion that scientists operate something that might be called 'the scientific method' the existence of which, as he rightly says, is a myth. Of the leading philosophers of science, however, it was only Francis Bacon and John Stuart Mill who put before the public an integral body of thought - an organon - that could pass as an exposition of 'the scientific method'. Popper did not, nor did Kuhn. Among Beveridge's many causes of complaint is that philosophers of science have "failed to appreciate the cardinal role that chance and opportunism play in research, and most have dismissed the subject as hardly worthy of their serious consideration". 
But what form could such a consideration take? If the story of the remarkable conjunction of events that led to the discovery of penicillin were recounted to a philosopher, what could he say except "Why, gee, what amazing strokes of luck!'”. If Beveridge himself were a little more philosophical about the matter, he would see that there is an inherent bias in our estimate of the contribution of good fortune to scientific research: we can all recognize when good fortune leads to a discovery or enlarges the understanding, but from the very nature of things we cannot know how often bad luck deprives us of the chance of making a discovery we might otherwise have made.

The most interesting paragraphs in Beveridge's book are those in which he deals with various expedients for promoting the flow of original ideas. Not all are convincing: the more I read and reflect upon the virtues of 'lateral thinking', the more I wonder what all the fuss is about. To be sure, we should all try to be adventurous in our thinking and try to get out of familiar ruts; but this is advice such as Polonius might have given - it cannot come to anyone as a revelation.

Beveridge criticizes Popper, as others have, for failing to throw much light on the process of ideation - the process by which new hypotheses come into being. Popper rebuts this charge perfectly adequately by pointing out that his work is mainly upon the logic of scientific discovery, and that ideation is outside logic and is a logically unscripted process. However Popper is fully aware of the central importance of having ideas as the generative act in scientific enquiry. In spite of Beveridge's criticisms I believe him to be more indebted to Popper than he realizes. In his final chapter, for example, he is clearly feeling his way towards the concept that Popper embodied in the notion of a 'Third World' (Popper's Third World; see Nature 241, $293 ; 1973$ ), though Beveridge clothes it in the tiresome terminology of 'hardware' and 'software' - an inappropriate terminology in this context because many ideas and conceptions are embodied in hardware such as machinery, buildings, institutions and so on.

One of the passages in which Beveridge seems to lack philosophic understanding is that in which he deals with frauds. In recounting the Piltdown hoax, brought up to date by incorporating Stephen Jay Gould's suggestion that the principal conspirator was none other than Teilhard de Chardin, he says that its main interest is to show "that even the scientific Establishment can be fooled by evidence that in retrospect is seen to be an obvious fake"; but does not Beveridge realize that science, like banking and government and - if that wise man Kenneth Clark is to be believed - civilization itself, rests upon confidence. When we go about our business we do not expect our colleagues and coworkers to be liars; nor do we scrutinize their statements with wary circumspection, in the manner of men on their guard. If we did so there would be no scientific business to transact. In going on to describe Paul Kammerer's fraud, Beveridge says Kammerer's views on the nature of inheritance were quite incompatible with those of neo-Darwinists "who believed that evolution was due solely to the selection of chance mutations that favour survival". This is a travesty of neo-Darwinism, but it would take too long to explain why.

Accounts of the Summerlin scandal and the fraud implicating Sir Cyril Burt pad out the book readably, but their inclusion may give a rather distorted picture of science to the young scientists who are among those to whom the book is addressed. I surmise - for there can be no proving such a statement - that for every scientist who fiddles his results there are a thousand who do not, and for every scientist who waxes fat on the proceeds of deception a thousand others spend sleepless nights and days of sick anxiety for fear that they have been guilty of a factual misrepresentation - or even, what does not matter nearly so much, of propounding an erroneous hypothesis.

" . . . most eminent scientists I know do have a lively sense of humour" says Beveridge - a characteristic he chooses to

\section{Freudian variations}

\section{Stuart Sutherland}

Freud: The Man and the Cause. By Ronald W. Clark. Pp.652. (Cape/Weidenfeld \& Nicolson/Random House: 1980.) £9.95, $\$ 19.95$.

IMAGE
UNAVAILABLE
FOR
COPYRIGHT
REASONS

FREUD was nearly 40 when he began to develop the psychoanalytic ideas for which he is remembered, but even as a youth he was convinced that he would be a famous man. From the age of 21 he periodically tried to destroy all records of his private life in a deliberate attempt to make difficulties for his biographers, each of whom would "be right in his opinion of "The Development of the Hero'." The latest to take up Freud's challenge is a highly illustrate by referring to Waddington's witless and disagreeable acronym COWDUNG which stands for 'conventional wisdom of the dominant group'.

Beveridge has some wider views on science in education which $I$ find as difficult to accept as many of those that relate to science itself. He writes that ". . . it would benefit everybody if the education of scientists included more studies in the humanities . . .'. I wonder: my own view, as ill-founded as his own, is that the young scientist who has not the initiative and the will to read books or listen to music or visit galleries will be bored out of his mind by lectures of the quality he is likely to receive on subjects such as 'the English novel' or 'the origins of the Romantic movement in Germany'. It would be a different story, of course, if an Ernst Gombrich or Kenneth Clark were to be found on every campus; but what can be found on every campus are libraries, radio, television, records and enthusiasts eager to share their enthusiasms - all of which may help to enlarge human sensibilities or human understanding.

Sir Peter Medawar is Head of the Transplantation Biology Section, Medical Research Council's Clinical Research Centre, Harrow, Middlesex.

professional biographer, Ronald Clark, who has already tackled Einstein, J. B. S. Haldane and Bertrand Russell. Fortunately for Clark, Freud's correspondents did not always obey his injuction to destroy his letters and considerable new material has come to light since Ernest Jones wrote the mammoth official biography.

The standard view of Freud's life, as put forward by Jones and other followers, is that he was indeed a hero. They argue that his theories were for long either ignored or derided because of their shocking sexual content, he was denied promotion, he fought with the world in "splendid isolation", and psychoanalysis emerged almost entirely from his own head (or genitals) as a result of his heroic selfanalysis. Freud, himself, in his autobiographical writings did everything he could to encourage this view.

In recent years, several scholars have attempted to modify the myth of Freud's heroism. His ideas received considerable support almost from the outset; to the extent to which they were rejected, it was because they were old-fashioned (for example, his attribution of some neuroses to masturbation) or obviously wrong (for example, his belief that many neurotics had been sexually seduced in infancy by an older person). At no time was he isolated from the rest of the scientific community, and many of his ideas were either modifications of existing lines of thought 